\title{
Critical Viewpoints on the Management of Conflict in Multi-National Construction Projects
}

DOI 10.5592/otmcj.2014.2.6 Research paper

\section{Keywords}

Construction, Conflict, Management, Multi-cultural, Multi-national

\section{Ilknur Akiner}

Akdeniz University University,

Dept. of Architecture, Campus,

Antalya 07058, Turkey,

ilknurakiner@gmail.com

INTERNATIONAL CONSTRUCTION MARKETS ARE INCREASINGLY TAKING ECONOMIC ADVANTAGE OF THE GLOBAL WORKFORCE. IT IS COMMON ON INTERNATIONAL PROJECTS TO FIND MULTI-CULTURAL PROJECT TEAMS LOCATED IN MULTIPLE COUNTRIES. Conflict management is becoming ever more important due to the rapid changes that are common in the current construction business environment. Global change, cultural diversity within multi-national project teams, and complexity are a few of the reasons that managing conflict is a critical skill for project team leaders. Results of this research provide an overview and describe multi-national construction projects, in which construction industry participants play an important role regarding the organization and performance, through a review of the published literature. Critical viewpoints of the paper and literature survey outcomes point in the direction that understanding multi-national or multi-cultural performances within construction projects can be a serious tool for dispute avoidance between the parties involved. 


\section{INTRODUCTION}

International business is not a new phenomenon. International business has occurred since before the time of Christ, when the Phoenician and Greek traders were sending representatives to sell their products around the Mediterranean Sea (Ball and McCulloch, 1993). Increasing impact of globalization and internationalization in the construction market requires interaction with expanding cross-cultural and multi-national construction projects. The literature indicates that various cultural factors have a significant influence on the management of construction projects and project outcomes. Accordingly, attention should be paid to cultural issues, especially in international projects (Liu and Fellows, 2008; Zuo and Zillante, 2008). It is therefore important to acknowledge the impact of different cultural backgrounds on attitudes and behaviors of participants through the organizations to collaborate in multi-national construction projects. Dealing with cultural issues will thus become an important aspect of a manager's role, both in general and in the construction context. Therefore, the impact of culture is crucial on conflict management within the context of international construction.

The nature of the construction industry is competitive, high risk, and uncertain. Nevertheless, construction management is very important and crucial for the growth and performance of construction industry. The main objective in the construction industry is to deliver a high-quality project within the schedule, within the budget, in a safe manner, and with the least number of conflicts, disputes, claims, and litigation (Zhang, 2008). According to Tijhuis (2008), the construction industry is a "people's business" and influences all the participants involved in the construction process.

The construction realization process is a complex of interdependencies between individual transactions among construction project participants (Liu and Fellows, 2008; Li Yi and Zhang, 2008). Hence, the performance, survival, and success of the project depend upon project transactions within the construction realization process (Liu and Fellows, 2008). This realization process requires the joint effort of a temporarily assembled organization with many different parties, each having different goals and expecting to maximize its own benefits (Li Yi and Zhang, 2008). Since differences exist in perception and goals among partners to a project, conflicts in the construction environment are inevitable. Conflicts can quickly turn into disputes if not properly handled. Dispute is regarded as a form of conflict that needs resolution (Cheung and Suen, 2002).

In many international joint ventures (JVs), the vast number of interdependent component transactions, coupled with diversity among participants leads to complexity and, consequently, boundary management issues and risks (Liu and Fellows, 2008). Therefore, according to Das and Teng (1999), the partner firms may not work together efficiently because of incompatible organizational routines and cultures. It is this process of culture in action, i.e., the development of a new culture for the JV, which is the source of many conflicts and a major contributor to the failure of many JVs (Swierczek, 1994).

Zuo and Zillante (2008) found that in an international project, the attitudes and behavior of participants are affected by i) National culture of all participants; ii) Differences between these national cultures; and iii) The project culture. They also determine that a strong project culture will be able to override the national culture of project team members. Zhang and Liang (2008) claimed that the fragmentation of the construction industry brings difficulties in managing a construction project. In addition, complexities in international construction manifest themselves in the execution of the contract, especially those that are caused by the cross-cultural differences. Since global projects involve interactions among individuals, organizations, and agencies from diverse national backgrounds and cultural contexts, problems inevitably arise from the additional misunderstandings, increased transaction costs, friction between project participants, and coordination and communication difficulties (Mahaligam and Levitt, 2007). Consequently, the performance of international projects declines (Zhang and Liang, 2008). The aim of this paper is to establish a valid foundation for further research on the impact of cultural issues on conflict causation for multinational construction projects through a literature survey. This research attempts to provide some insights into the conflict and arrive at results that might help to improve multi-national project environments through participant- and performance-based management in the construction industry.

\section{Conflict, Management, and Effects of Culture}

Construction projects inherently have the potential for conflicts within participants. The construction industry is subject to more conflicts, disputes, and claims more than many other industries (Enshassi and Rass, 2008). According to Latham (1994) project procurement and construction disputes are two of the major concerns in the construction industry. Therefore, conflict and disputes are causing major damage to the industry. Since a growing number of contractor firms initiate or expand cross-border activities, cultural influences on managerial characteristics must be addressed within the construction context specifically. Due to the nature of the construction industry, the successful changing of a culture or working with another national culture requires clear management and commitment at all levels of organizations within the construction industry (Akiner and Tijhuis, 2008). 
Due to the risky, uncertain, and competitive nature of the construction industry, conflicting goals among the different participant parties involved in a project are compelled to prioritize their own interests and benefits. In many cases this may lead to the increase in number of disputes, expensive claims, and costly litigations, resulting in projects not completed within time and budget (Zhang, 2008).

Conflicts of interest in international projects are more pronounced than in projects within one nation, and it is infinitely more difficult to uncover hidden interests, values, and standpoints. In addition, conflicts can more easily develop over issues that are grounded in differences in values. Behavioral reactions are deeply rooted in every culture. Even though the participant parties may be intellectually aware of their differences, when one party trespasses on the other party's threshold of intolerance, the seed to conflict is sown. It takes little to trigger a sense of antipathy and repulsion, and then conflict, if one's values are challenged and misunderstandings escalate into conflict (Vonsild, 1996). Conflict resolution is one of the most important cultural elements of multi-national construction projects. Grisham (2006) described conflict as an integral part of human interaction between people, groups, cultures, firms, and countries. If guided, conflict can be healthy and productive. However, if ignored, conflict may lead to disastrous consequences, including the deterioration of long-term relationships. In the international marketplace, the potential for conflict is extremely high as cultural beliefs and customs collide with regularity (Grisham, 2006).

According to Fellows and Liu (2008) there are three main perspectives on conflict: functionalist, behaviorist, and interactionist. The traditional functionalist perspective regards conflict negatively as disruptive. Behaviorists are neutral, regarding conflict between individuals and groups as inevitable and differences in the consequences of conflict arising through differences between people's perceptions, personalities, interests, expertise, and goals. Interactionists view conflict as carrying out useful functions to ensure social dynamism and to enhance decisions (Fellows and Liu, 2008). Conflict management may be defined as a process that involves designing effective strategies to minimize the dysfunctions of conflict and enhancing the constructive functions of conflict in order to enhance learning and effectiveness of an organization (Rahim 2001).

Yates (2003) stated that contractors' claims are often opportunistically inflated, exaggerated or even spurious, and clients (and their staff/consultants) frequently respond with reciprocal opportunism by rejecting contractors' claims out of hand. Theoretically, it is possible that a claim genuinely made by one party could genuinely be disputed by the other, involving no opportunistic behavior by either party (Enshassi and Rass, 2008). In today's complex construction projects, resolving disputes has become an inevitable part of a project manager's work (Cheung, 1999). Leaders must have the ability to confront, manage, or resolve (depending upon the circumstances) conflict effectively (Grisham, 2006).
A better understanding of influential cultural factors will help to reduce and manage conflicts in international construction projects. Recognizing and sensibly manipulating cultural differences could allow improvements in the efficiency and profitability of international projects (Chan and Tse, 2003). Conflict inevitably exists in JV projects, which may lead to project failure (Liu and Fellows, 2008). However, some organizational theorists (Mullins, 2005) believe that if conflict is managed properly, it can increase organizational effectiveness. Julian (2005) reports that the presence of two or more parent organizations from different cultures and geographic locations tends to make an international JV a complex form of organization structure that is often difficult to manage.

Conflict management styles can be defined as styles of behavior with which interpersonal conflict may be handled (Rahim 2002). There are two basic dimensions on the styles of handling interpersonal conflict: concern for self and concern for others (see figure 1). Rahim (2001) identified five main conflict management approaches (see Table 1). It is important to note that these two dimensions portray the motivational orientations of a given individual during conflict (Rahim 2002). Ilban

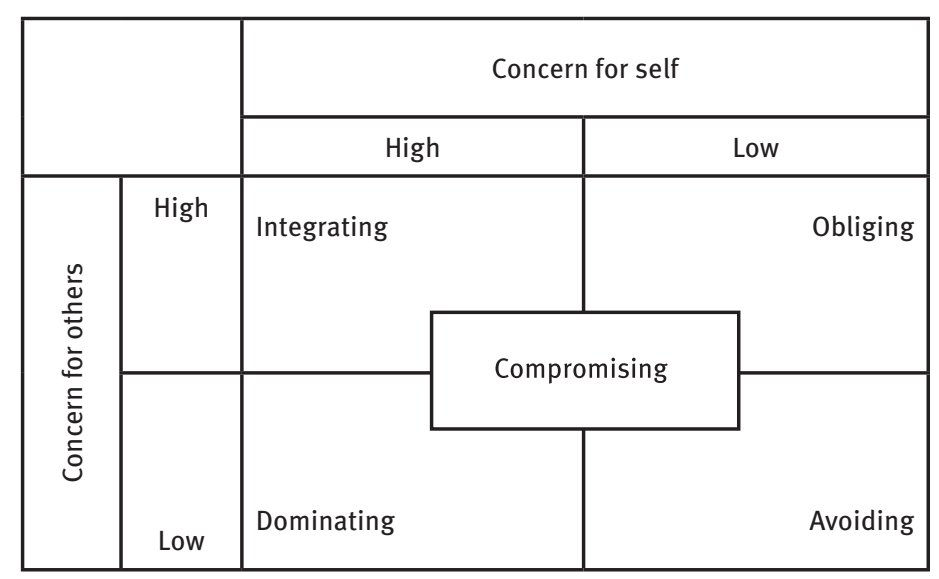

Figure 1. A two-dimensional model of the styles of handling interpersonal conflict (Rahim 2001) 


\begin{tabular}{l} 
Dominating \\
\begin{tabular}{l} 
Enforcement one's own interests, even at the expense of those of the other party. \\
Integrating \\
Compromising \\
Avoiding \\
A give-and-take approach in order to reach a midpoint agreement. \\
\hline Obliging \\
Evasion of the conflict topic, the other conflict party, or the situation altogether.
\end{tabular} \\
\hline
\end{tabular}

Table 1. Conflict Management Styles of Rahim (2001)

and Giritli (2008) examined cultural aspects of conflict behavior within the context of international construction. Results of their study demonstrated that self-concept seems to be good predictor for avoiding, compromising and integrating conflict behaviors in the construction context. They also found that in a conflict situation, independent persons tend to use avoiding and compromising styles, whereas interdependent persons tend to use integrating. Ilban and Giritli (2008) used in their research a five interpersonal conflict management styles have been identified by some scholars (Rahim, 2001; Rahim and Magner, 1994, 1995; Van de Vliert and Kabanoff, 1990) is a better, more appropriate conceptualization for explaining interpersonal conflict management phenomena. Definitions of five interpersonal conflict management styles used in the research of Ilban and Giritli (2008) are provided as follows based on the dual concern model of Rahim and Bonoma (1979) and Rahim (2001).

To examine the relationship between culture and conflict management styles in an organizational setting, ElsayedEkhouly and Buda (1996) questioned employees in companies located in the Middle Eastern countries as well as in the United States. Their inventory data showed Middle Eastern executives to display more integrating and avoiding, while U.S. executives used more obliging, dominating, and compromising styles. Jordanian, Turkish, and U.S. managers were interviewed by Kozan (1989) about their conflict behavior toward superiors, peers, and subordinates. Regarding conflict management with peers, he found that managers of all three countries rather seem to avoid conflicts.

According to Hu et al. (2008) conflicts in multi-national construction projects are more critical than those in domestic projects. Conflicts in international construction projects are not easily solved based on international laws because construction management is regulated more by domestic laws than international laws. There are fewer international organizations that have set rules or customs for international construction, and those rules and customs are not compulsive in project management. Though Federatıon Internatıonale Des Ingenieurs Conseils (FIDIC) has developed several standard contract forms and arbitration regulations in last 40 years, disputes are popular in international construction projects and the resolution is costly and time-consuming (Hu et al., 2008). There are many different reasons for conflict in construction projects and some that appeared in the literature are listed in Table 2.

Fellows and Liu (2008) acknowledged that once conflict arises, it is difficult to control. Such difficulties are likely to expand geometrically in multi-cultural settings according to cultural distance perspectives and where the stakes are high, as on large, multi-national construction projects, especially those with high political profiles (Fellows and Liu, 2008). Hu et al. (2008) determined that international construction disputes primarily involve delays on interdependent construction phases due to mismanaged time, inefficient processes, and unclear contract terms that all undermine the business relationship between contractors, consultants, and clients. Project managers usually spend as much as $70 \%$ to $80 \%$ of their time resolving conflicts and disputes. Construction professionals need more knowledge and skills to manage and resolve conflicts and disputes efficiently and effectively, and the project progress and quality of the product will be improved (Hu et al., 2008).

In today's constantly changing global business environment, cultural issues and understanding different cultures have become an essential prerequisite for business success (Walker et al. 2003), especially for companies that operate in international markets and hire employees of different cultures. Mahalingam et al. (2007) investigated which institutional or cultural differences had the most significant impact on global projects. Thus, successful management of conflict must be sensitive to the objectives of the participants, their behavioral characteristics, and preferences/norms derived from culture. This valuation point of view acknowledges the possible existence of conflicts as early as possible for participants involved in project (Fellows and Liu, 2008). 


\begin{tabular}{|l|l|}
\hline \multicolumn{1}{|l}{ Items } & Source \\
\hline $\begin{array}{l}\text { Participants involved in multi-national construction projects and complex and dynamic } \\
\text { nature of construction business environment }\end{array}$ & Hu et al. (2008) \\
\hline $\begin{array}{l}\text { Ambiguous and inappropriate contracts, pursuit of project goals, poor performance } \\
\text { Encounters between cultures (i.e., strategic alliances, joint ventures) }\end{array}$ & Artama Wiguna and Scott (2006) \\
\hline $\begin{array}{l}\text { The different interpretations of the contract, quality of material, defects due to } \\
\text { workmanship, delays, cost increases }\end{array}$ & Fellows and Liu (2006) \\
\hline \begin{tabular}{l} 
Contracts, communications, procurement policies, design faults, the contractor \\
\hline $\begin{array}{l}\text { Payments, unfamiliarity with local conditions, uncertainty in the job description, risk } \\
\text { distribution, differences in doing business, shortcomings in the technical specifications, } \\
\text { inadequate communication, management, unrealistic expectations, knowledge use, } \\
\text { unfamiliarity with local law, unclear contractual provisions }\end{array}$
\end{tabular} & Chan and Suen (2005) \\
\hline $\begin{array}{l}\text { The tender process, process of design, construction and project management } \\
\text { Inappropriate contractual arrangements and cultural clashes }\end{array}$ & Ashworth) \\
\hline \begin{tabular}{l} 
Changes, inadequate documentation, interpretation of specifications, payments \\
\hline
\end{tabular} & Fryer et al. (2004) \\
\hline
\end{tabular}

Table 2. Items Leading to Conflict in Construction Projects

\section{Participants and Performance in Multi-national \\ Construction Projects}

The construction process starts with a client realizing a need for a construction product (a constructed facility). Various participants then need to be engaged to contribute toward the realization of this particular facility. Construction is thus a project-based activity with the involvement of numerous participants whose responsibilities are set out in contracts (Fellows et al., 2002). Realization of construction projects are essentially multi-participant activities. As such, diversification of participants involved in a project creates multiple objectives and interest within the construction project process. Multi-national construction projects bring together organizations and individuals from different countries and, therefore, almost inevitably, different cultures (Fellows and Liu, 2008). There are several important participants through the lifecycle of multi-national construction projects. However, the clients and the contractors are generally the primary players, and conflicts usually occur between these two participants within the construction phase. Cultural issues are expected to contribute to conflicts among parties to an international project and increase difficulties in the management of the project (Fellow and Hancock, 1994).

According to Fellows and Liu (2008), multi-national projects are increasingly undertaken through formal alliances between the primary participants. However, even if no formal alliance is executed, the interdependence between the activities of the participants requires informal alliancing. Given the high incidence of failures among formal alliances, identification and avoidance of reasons for failures are important, along with pursuit of potential for success, notably the selection of partners (Fellows and Liu, 2008).

Project participants have a vested interest in the success or failure of a project and the environment within which the project operates (Olander, 2007). Vested interest, in turn, can be viewed as the actual or perceived benefits or risks/harms from the activities of construction project management (Donaldson and Preston, 1995). Project participants may have a positive or a negative influence on the project. The challenge for the project team, hence, becomes one of implementing the project strategies such that positive stakeholder's influence is maximized and negative influence is minimized (Walker et al., 2008). In analyzing stakeholder management activities, it is useful to categorize stakeholders into two broad groups: primary and secondary stakeholders. Primary stakeholders are people or groups that have a legal contractual relationship to the project. Secondary stakeholders, on the other hand, are those who influence or are influenced by the project but are otherwise not regularly engaged in transactions with the project (Cleland and Ireland, 2007, p. 151). It is apparent that the client, the main contractor and subcontractors, the quantity surveyor, suppliers, and the like belong to the former group, while local communities and general public belong to the latter (Rowlinson et al., 2008). 
Ankrah and Langford (2005) investigated and identified the organizational cultures of architectural parties and contracting organizations by revealing specific cultural characteristics and orientations, establishing significant areas of difference and initiating discussion on some of the implications for conflicts and project performance. Their study investigates and identifies the cultural clash at the inter-organization level of two significant players in the project coalition, architects and contractors, on the premise that by revealing specific cultural characteristics and orientations, establishing significant areas of difference, and initiating discussion on some of the implications for conflicts and project performance, the context would be set for assessing and understanding the behavior of these project participants. The implications of the research conducted by Ankrah and Langford (2005) are that conflicts are likely to occur within the project coalition at the interface level where human interaction elements occur, which could detract from achieving project objectives. Awareness of these differences, however, improves the chances of achieving the right balance when constructing the team and this could lead to the development of synergy and good "project chemistry" with positive consequences for overall project performance (Ankrah and Langford, 2005).

A quantitative study undertaken by Leung et al. (2004) on project participants found team-related variables in the form of team conflict, cooperation and participation, and goal commitment to be critical factors influencing the final satisfaction outcomes of construction projects.

Saffold (1988) mentions that a strong culture has been hailed as a key to improved performance. Deal and Kennedy (1982) assert that a strong culture is the driving force behind continued success in American business. Segregation between participants and roles is one of the principal causes of poor performance (Latham, 1994). Transactions between the multi-national project participants, particularly early in the construction process promotes buildability, which reduces the conflicts. According to Soetanto et al. (2001), an essential ingredient of project performance is harmonious working relationships between participants.

It is widely agreed that a project has many stakeholders whose interests may be related or in conflict (PMBook Guide, 2004). A project manager shall seek the stakeholders input to the project in order to achieve project success (Wang and Huang, 2006). The Project Management (PM) literature requires that a project manager does not limit the project team within the boundaries of his/her own organization, but also includes other key stakeholders as part of the project team (PMBook Guide, 2004; Wang, 2003). Research results concluded by Wang and Huang (2006) show positive correlations between cost, time, and quality performance, which means project cost, time, and quality are not simply in conflict, and effective project teams also enhanced the project performance.

Zhang (2008) put forward that many disputes and conflicts exist and need to be solved properly in the construction industry. All participants involved in the project must recognize that each participant is a part of both the dispute and its resolution, and only when the participants acknowledge this principle, they can make a commitment to dispute resolution. In the current time, due to the confrontational relationship between the parties, the disputes and conflicts cannot be solved in a friendly and open environment, and are usually subject to litigation and arbitration after the project is completed, which are both expensive and time-consuming. These two methods of dispute resolution are significantly harmful to the project performance and success (Zhang, 2008). Rahim (2002) argues that organizations do not need conflict resolution but conflict management to minimize the dysfunctionality of conflict and maximize the attributes. Establishment of common objectives and common values are important objectives in the drive for greater cooperation and reduced conflict in construction projects (Kelly and Male 1993).

\section{Conclusion}

Successful procurement of a construction project in a construction project organization requires a project team participant's coalition toward a common objective. The aim of this research was to examine the relationship of conflict and culture in respect to the multinational construction project outcomes, such as performance and participants of the projects based on the literature survey. The study covers the conflict concept and its significant items, possible consequences, sources causing the conflict, its relation to performance and the culture in the literature related to the conflict circumstances, and its evaluation from the point of view of the management. Reviewing the literature is the limitation of the study and further research directions are included in the study. There have been a considerable number of studies on multi-cultural construction projects conducted in different disciplines. The interest in project culture of participants is derived from the belief that culture of a multi-national project organization has a direct impact on performance and conflict resolution. Culture can have a powerful positive effect on project organizational performance in a competitive construction environment. Intrinsically, culture has been identified as essential to performance improvement and conflict resolution studies. Tijhuis (2001) highlighted that construction industry participants must become more aware of the importance of culture on performance. Nevertheless, most scholars (e.g., Ankrah and Langford, 2005; Fellows and Liu, 2008) of culture in construction studies have conducted sufficient 
background research to enhance their understanding of the relationship between culture, conflict, and performance in the construction industry.

Conflicts often occur within multinational construction projects. Unresolved conflicts can seriously affect the proper functioning of construction project organizations. Culture plays an important role in achieving understanding and gaining cooperation between participants. Clearly, there is a sound basis in the literature for the performance of construction projects are influenced by the culture of the Construction Project Organization. Conflict must be considered as an effective technique for the management of the organizational problems and for the improvement of the construction organization. A deeper understanding of culture in multi-national construction project is imperative to the enabling of project participants to minimize the potential of conflict effects. Project organizations must respect different cultures and cross-cultural management. Furthermore, they must labor to understand and appreciate different cultures and mitigate the adverse effects of conflicts between the participants. In the construction industry, conflicts become natural facts due to many reasons, such as the faulty architectural or construction design decisions made by the architects and the engineers, the project team organization, the managers who are reconvened in each project, the amount of the work, insufficiency of the labor force, and faulty construction productions.
According to the results of the study and literature survey there might be some recommendations for further studies. Multi-national construction projects are not independent from the domestic construction market. Conflicts in international construction projects could be resolved effectively through the project's internal structure and external third-party organizations. Therefore, the primary players of the construction industry should be studied in detail. Comprehensive surveys based on the cultural comparisons of nations are required to determine the big picture of the construction industry.

\section{References}

Autodesk, Abeysekera, V. (2003) Understanding culture in an international construction context, Perspectives of Culture in Construction, CIB Publication, 275, 39-51.

Adriaanse, J. (2005) Construction contract law: The essentials. Palgrave-Mac, Millan, New York.

Akiner, I. and Tijhuis, W. (2008) Cultural Variables and the Link Between Managerial Characteristics In Construction Industry: Reflections from Turkish and Dutch Examples, International Conference on Multi-National Construction Projects "Securing high Performance through Cultural awareness and Dispute Avoidance" Shanghai, China, November 21-23, 2008.

Ankrah, N. A., and Langford D. A.(2005) Architects and contractors: a comparative study of organizational cultures, Construction Management and Economics, 23(7), 595-607.

Ankrah, N.A. and Proverbs, D. (2004) Treading the softer areas of construction management: a critical review of culture. In: Khosrowshahi, F. (Ed.), 2oth Annual ARCOM Conference, 1-3 September 2004, Heriot Watt University, Association of Researchers in Construction Management, Vol. 1, 551-8.

Artama Wiguna, I. P. and Scott, S. (2006) Relating risk to project performance in Indonesian building contracts, Construction Management and Economics, 24 (11), 1125.

Ashworth, A. (2005) Contractual Procedures in the construction industry. Pearson Longman, New York.

Ball, D.A. and McCulloch, W.H. (1993) International business: introduction and essentials, 5 th edition, Irwin, 1993, University of California, ISBN 0256106525 , 9780256106527.

Chan, E. H., and Tse R. Y.(2003) Cultural Considerations in International Construction Contracts. Journal of Construction Engineering and Management, 129(4), 375-381.

Chan, E.H.W. and Suen, H.C.H. (2005) Dispute resolution management for international construction projects in China, Management Decision, 43(4), 589-602.

Cheung, S., and Suen, H. (2002) A multi- 
attribute utility model for dispute resolution strategy selection, Construction Management and Economics, 20(7), 557568.

Cheung, S.O. (1999) Critical Factors Affecting the Use of Alternative Dispute Resolution Processes in Construction, International Journal of Project Management Vol. 17, No. 3, pp. 189-194.

Cleland, D.I. and Ireland, L.R. (2007) Project management: strategic design and implementation, $5^{\text {th }}$ edn. New York: McGraw-Hill.

Das, T. K., Teng, B. S. (1999) Managing risks in strategic alliances, The Academy of Management Executive, 13, 4, 50-62.

Deal, T. E. and Kennedy A. A. (1982) Corporate cultures: the rites and rituals of corporate life. Reading, Mass: Addison-Wesley.

Donaldson, T. and Preston, L. (1995) The stakeholder theory of the corporation: Concepts, evidence, and implications. Academy of Management Review, 2o(1), pp. 65-91.

Elsayed-Ekhouly, S.M. and Buda, R. (1996). Organizational conflict: A comparative Analysis of Conflict Styles Across Cultures, International Journal of Conflict Management, 7, 71-81.

Enshassi, A. and Rass, A.A. (2008) Dispute Resolution Practices in the Construction Industry in Palestine, International Conference on Multi-National Construction Projects "Securing high Performance through Cultural awareness and Dispute Avoidance" Shanghai, China, November 21-23, 2008.

Fatehi, K. (1996) International Management - A Cross-Cultural and Functional Perspective, Prentice-Hall, New Jersey.

Fellows, R. and Liu, A. (2008) A CultureBased Approach to the Management of Conflict on Multi-National Construction Projects: Participants and Performance, International Conference on Multi-National Construction Projects "Securing high Performance through Cultural awareness and Dispute Avoidance" Shanghai, China, November 21-23, 2008.

Fellows, R. and Liu, A. (2006) Culture as a Category of Risk in Construction, The Joint International Conference on Construction Culture, Innovation and Management (CCIM), Sustainable Development through Culture and Innovation, Edited by $\mathrm{Dr}$ Mohammed Dulaimi The British University in Dubai, UAE, pp: 16-18.

Fellows, R., Langford, D., Newcombe, R. and Urry, S. (2002) Construction management in practice, Oxford, Blackwell Science.

Fellow, R. F., and Hancock, R. (1994) Conflict resulting from cultural differentiation: An investigation of the new engineering contract, Council of International Construction Research and Documentation Proc. on Construction Conflict: Management and Resolution, Rotterdam, The Netherlands, 259-267.

Fryer, B., Egbu, C., Ellis, R. and Gorse, C. (2004) The Practice of Construction Management, Blackwell Publishing, Oxford.

Grisham, T. (2006) Cross-Cultural Leadership, A thesis submitted in fulfillment of the requirements for the Degree of Doctor of Project Management, School of Property, Construction and Project Management Royal Melbourne Institute Technology University.

Hall, M.A. (1999) International construction management: the cultural dimension, PhD thesis, Liverpool John Moores University, Liverpool.

Hu, W., Chen, J., Wang, G. and Ren, Z. (2008) Dispute administration and resolution in international construction projects, International Conference on Multi-National Construction Projects "Securing high Performance through Cultural awareness and Dispute Avoidance" Shanghai, China, November 21-23, 2008.

Ilban, T. and Giritli, H. (2008) Cultural Aspects of Conflict Management in International Construction, International Conference on Multi-National Construction Projects "Securing high Performance through Cultural awareness and Dispute Avoidance" Shanghai, China, November 21-23, 2008.

Julian, C. (2005) International Venture Performance in South East Asia. Edward Elgar Publishing Inc. USA.

Kelly, J. and Male, S. (1993) Value Management in Design and Construction: the economic management of projects, E \& FN Spon, London.

Kivrak, S., Ross, A. and Arslan, G. (2008) Effects of Cultural Differences in Construction Projects: An Investigation among UK Construction Professionals, International Conference on Multi-National Construction Projects "Securing high
Performance through Cultural awareness and Dispute Avoidance" Shanghai, China, November 21-23, 2008.

Korzilius, L. P. (1988) A system and contingency analysis applied to construction projects of exceptional architectural design. (Available at http://www.lesterkorzilius.com/pubs/ $\mathrm{msc} / \mathrm{MSC}-\mathrm{o} . \mathrm{htm})$.

Kozan, M.K. (1989) Cultural Influences on Styles of Interpersonal Conflicts: Comparisons Among Jordan, Turkish and US Managers, Human Relations, 42, 789-799.

Kumaraswamy, M. M. and Yogeswaran, K. (1998) Significant sources of construction claims, The international construction law review, 15(1), 144-160.

Latham, M. (1994) Constructing the team, Final report of the government/industry review of procurement and contractual arrangements in the United Kingdom construction industry, London, HMSO, Department of Environment.

Leung, Mei-Yung; Thomas Ng, S. and Cheung, Sai-On (2004) Measuring construction project participant satisfaction, Construction Management and Economics, 22 (3), 319.

Li Yi, M. and Zhang, P. (2008) A comparative study of arbitration and mediation to resolve disputes on sites in Hong Kong, International Conference On Multi-National Construction Projects "Securing high Performance through Cultural awareness and Dispute Avoidance" Shanghai, China, November 21-23, 2008.

Liu, A.M.M. and Fellows, R. (2008) Organisational Culture of Construction Joint Ventures: Case Studies in Hong Kong, International Conference on Multi-National Construction Projects "Securing high Performance through Cultural awareness and Dispute Avoidance" Shanghai, China, November 21-23, 2008.

Liu, A and Fellows, R (1999) Cultural issues, in Procurement systems : a guide to best practice in construction, eds. $P$ McDermott and SM Rowlinson, Routledge, E \& FN Spon, New York, London.

Loosemore, M. and Al Muslmani, H.S. (1999) Construction project management in the Persian Gulf: inter-cultural communication, International Journal of Project Management, 17, 95-100. 
Mahalingam, A., and Levitt, R. E. (2007) Institutional Theory as a Framework for Analyzing Conflicts on Global Projects. Journal of Management in Engineering, 133(7), 517-528.

Mullins, L. J. (2005), Management and organisational behaviour. 7 th edn. Harlow: Pearson Education.

Newcombe, R. (2003) From client to project stakeholders: a stakeholder mapping approach, Construction Management and Economics, 21 841-848.

Ngowi, A.B. (2001) Impact of culture on the application of TQM in the construction industry in Botswana. International Journal of Quality and Reliability Management, vol. 17 , no. 4/5, pp. 442-452.

Olander, S. (2007) Stakeholder impact analysis in construction project management. Construction Management and Economics, 25(3), pp. 277-287.

Palmer, M. (2002) How an effective project culture can help to achieve business success: establishing a project culture in Kimberly-Clark Europe, Industrial and Commercial Training, 34(3), 101-105.

Pheng, L.S. and Alfelor, W.M. (2000) Crosscultural influences on quality management systems: two case studies, Work Study, 49(4), 134-144.

Rahim, M.A. (2002) Toward a Theory of Managing Organizational Conflict, International Journal of Conflict Management. 13 (3): 206.

Rahim, M.A. (2001) Managing Conflict in Organizations, Quorum Books, 3rd ed.

Rahim, M.A. and Magner, N. R. (1995). Confirmatory Factor Analysis of the Styles of Handling Interpersonal Conflict: FirstOrder Factor Model and Its Invariance Across Groups, Journal of Applied Psychology, 80, 122-132.

Rahim, M.A. and Magner, N. R. (1994). Convergent and Discriminant Validity of the Rahim Organizational Conflict Inventory-II, Psychological Reports, 74, 35-38.

Rahim, M.A. and Bonoma, T.V. (1979) Managing Organizational Conflict: A Model for Diagnosis and Intervention, Psychological Reports, 44, 1323-1344.

Rowlinson, S., Koh, T.Y. and Tuuli, M.M. (2008) A Cultural Perspective on Stakeholder Management In The Hong Kong Construction Industry, International
Conference on Multi-National Construction Projects "Securing High Performance Through Cultural Awareness And Dispute Avoidance" Shanghai, China, November 21-23, 2008.

Saffold, G.S. (1988) Culture traits, strength and organizational performance: moving beyond strong culture, Academy of Management Review, 13(4), 546-558.

Shore, B. and Cross, B.J. (2005) Exploring the role of national culture in the management of large-scale international science projects, International Journal of Project Management, 23, 55-64.

Soetanto, R., Proverbs, D.G. and Holt, G.D. (2001) Achieving quality construction projects based on harmonious working relationships: clients' and architects' perceptions of contractor performance, International Journal of Quality and Reliability Management, 18 (4/5), 528-548.

Swierczek, F.W. (1994) Culture and conflict in joint ventures in Asia, International Journal of Project Management, 12, 1, 39-47.

Tijhuis, W. (2008) Understanding MultiCultural Performance in Construction: $A$ Tool for Dispute Avoidance?, International Conference on Multi-National Construction Projects "Securing High Performance Through Cultural Awareness And Dispute Avoidance" Shanghai, China, November 21-23, 2008.

Tijhuis, W. (ed) (2001) Culture in Constructionpart of the deal?, CIB Publications.

Van de Vliert, E., and Kabanoff, B. (1990). Toward Theory-Based Measures of Conflict Management, Academy of Management Journal, 33, 199-209.

Vonsild, S. (1996) Management of Multicultural Projects: How Does Culture Influence Project Management?, Paper presented at 1996 World Congress on Project Management, International Project Management Association, "Challenge of the 21st Century: Balancing Team and Task, Paris, June, 1996. (avaliable at: http://www.ipmacourse.com/articles/c/ How $\%$ 20does $\% 20$ culture\%2oinfluence $\% 20$ project\%2omanagement.pdf).

Walker, D.H.T., Bourne, L., and Rowlinson, S. (2008) Stakeholders and the supply chain; In Walker, D.H.T. and Rowlinson, S., eds. Procurement system: a cross-industry management perspective. Abington: Taylor and Francis, pp. 70-100.
Walker, D.M., Walker, T., and Schmitz, J. (2003) Doing Business Internationally - The Guide to Cross-Cultural Success, New York, McGraw-Hill.

Wang, X. (2003) Realizing your objectives: project management as methodology and values/beliefs. Beijing: The People_s Publishing House; [in Chinese].

Wang, X. and Huang, J. (2006) The relationships between key stakeholders_project performance and project success: Perceptions of Chinese construction supervising engineers, International Journal of Project Management 24 (2006) 253-260.

Yates, D. (2003) "Can claims and disputes (in construction contracts) be prevented or reduced?" Building Journal Hong Kong China.

Zhang, Y. (2008) Partnering: A good approach to dispute resolution in construction management, International Conference on Multi-National Construction Projects "Securing High Performance Through Cultural Awareness And Dispute Avoidance" Shanghai, China, November 21-23, 2008.

Zhang, S. and Liang, X. (2008) Culture Studies In International Construction Contracting: An Overview, International Conference on Multi-National Construction Projects “Securing High Performance Through Cultural Awareness And Dispute Avoidance" Shanghai, China, November 21-23, 2008.

Zuo, J. and Zillante, G. (2008) Construction project culture vs. national culture, International Conference on Multi-National Construction Projects "Securing High Performance through Cultural Awareness and Dispute Avoidance" Shanghai, China, November 21-23, 2008 